\title{
The Practice of Letter Writing: Skills, Models, and Early Modern Dutch Manuals
}

\author{
Marijke van der Wal and Gijsbert Rutten \\ Leiden University, The Netherlands
}

In this paper, formulaic language in seventeenth- and eighteenth-century Dutch private letters is compared with formulae presented in letter-writing manuals. The most frequent formulae in the Dutch letters show a striking similarity with those found in private letters from other language areas. Such an eye-catching similarity points clearly to a shared European epistolary tradition which has been the topic of various previous studies. Being aware of this widespread tradition, we address the question of how letter writers acquired the formulae characteristic of that tradition by first discussing briefly literacy in the Dutch Republic and by subsequently taking into consideration the possible influence of theory and models provided in letter-writing manuals. After having established similarities and differences between the 'theory' of the more modest manuals or schoolbooks and actual practice of private letters, we conclude that direct influence of letterwriting manuals on the actual practice is not very likely. In the same vein as claims made for other languages, we furthermore argue that letter-writing conventions such as formulae were rather acquired by active participation in writing practice.

KEYWORDS letter writing, literacy, formulaic language, formulae, letter-writing manuals, epistolary tradition, private letters, the acquisition of writing skills

\footnotetext{
There was an ancient custom, which Seneca says was preserved to his own day, that letters should begin: 'If you are well, I am glad. I am well also' /Si vales bene est, ego quoque valeo. [...] This formula was expressed in various ways: 'If you are well, I am well'; 'If you are well, I am glad; I am well' Si vales bene est, ego valeo/ Si vales, valeo; si vales bene est, ego valeo etc. [...] This formula disappeared from use (...). But it is not so obsolete that it cannot be added, and at times should be, to lend adornment to a 


\section{Introduction: Letters as Loot}

On I7 November I67I, at the eve of the Third Anglo-Dutch War (I672-74), Grietje Paals wrote an elaborate letter of three full pages to her husband, skipper Jan Paal, and their son Jacob, who both had sailed on a Dutch East Indian Company ship to the East. ${ }^{\mathrm{I}}$ At the same time, one of her other children, Jan, who was still a pupil at school, wrote the following message to his father:

I. beminde vader en broer ick laet ul wete onser

2. gesontheyt hope dat met vader en broer oock soo is

3. vader ul breijf ontfangen enoock vandach een brief

4. van mij broer mijn vader en broer gesontheijt

5. veerstan het twelck ons lief was omte hooren

6. vader ul stuster dochtert verlanct nasijeden rock

7. en ick na en aep mijn moeder en mijn suster

8. en ick ul soon wensche vader en broer duesent

9. goede nach ickul soon Jan pael

'dear father and brother I let you know our

health hope that with father and brother also likewise is

father your letter received and also today a letter

from my brother my father's and brother's health

understood which was dear to us to hear

father your sister daughter desires a silk skirt

and I [desire] a monkey my mother and my sister

and I your son wish father and brother thousand

good night[s] I your son Jan Pael' (lit. translation with elements added between square brackets).

See also Figure I.

Jan's little note shows clearly that he was fully aware of particular letter-writing conventions: he starts with what we refer to as a health formula (lines I to 5), intersected by the confirmation of the receipt of previous letters, and ends with a well-known closing formula, wishing his father and brother a thousand good nights. Actually, the bold lines 6 and 7, which convey his sister's and his own wishes, are the only non-formulaic phrase in the brief note.

Neither his brief note nor his mother's elaborate letter, sent through a friend (met vryent dye god gheleyde 'with a friend who God may lead'), reached their destination. Both are among the approximately 40,000 Dutch letters that, with all others papers, both commercial and private, were confiscated aboard ships taken by the English fleet and by private ships (privateers) during the frequent warfare between England and the Netherlands which took place from the second half of the seventeenth to the early nineteenth centuries. These papers were considered evidence in the legal

I The $s$ morpheme of names such as (Grietje) Paals indicates 'wife of' or 'daughter of'. 


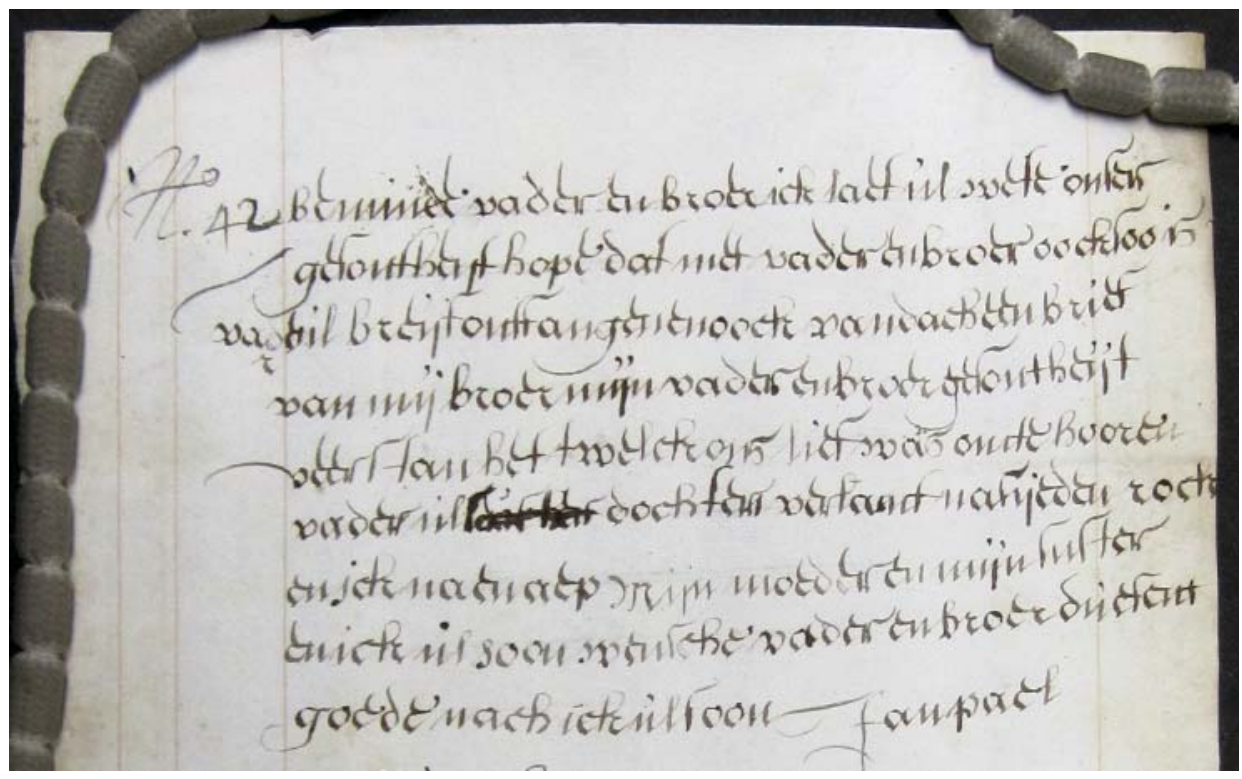

FIGURE 1 Jan Paal's note.

procedure that followed, when the High Court of Admiralty (HCA) had to decide whether the conquered ships were taken lawfully. After the final decision, the confiscated papers stayed in the HCA's Archives, and, miraculously, they survived. At present they are kept in the British National Archives (Kew, UK).

It is the I5,000 private letters, in particular, sent by people of all social ranks, men and women alike, that make this recently rediscovered source so interesting for historical linguists. They are excellent material for a sociohistorical linguistic approach, and offer an unprecedented opportunity to gain access to the everyday language of the past. Since 2008 , these seventeenth- and eighteenth-century private letters have been at the core of the research programme Letters as Loot. Towards a non-standard view on the history of Dutch at Leiden University (cf. Van der Wal et al., 20I2: I $39-43) .^{2}$

When examining the letters in our Letters as Loot corpus, we find a large variety of what appear to be formulae, which, moreover, show a striking similarity with those found in private letters from other language areas. Such an eye-catching similarity points clearly to a shared epistolary tradition in Western Europe which has been the topic of various studies (cf. Nevalainen, 200I; Poster and Mitchell, 2007 and references there). Being aware of this widespread tradition, the observer may wonder how the formulae characteristic of that tradition were acquired by letter writers. In other words: how did Jan Paal and many others learn their formulaic language? We will address this question when dividing it into two separate issues: how did they

2 For further information see <www.brievenalsbuit.nl>. 
acquire writing skills and how did they learn to write a letter? The former issue leads us to discussing briefly literacy in the Dutch Republic of the seventeenth and eighteenth centuries and the latter to taking into consideration the possible influence of theory and models provided in letter-writing manuals.

In this article we thus combine epistolography and epistolary theory (cf. Poster and Mitchell, 2007: 3), when examining the actual letter-writing practice, as shown in our Letters as Loot corpus, and investigating the influence of the 'theory' in letter-writing manuals on that practice. In section 2, we discuss writing skills and literacy. In section 3 , we present a selection of formulae found in our letters. In section 4 , we focus on a few Dutch letter-writing manuals and compare formulae found in our letters with those that occur in these manuals. In section 5, we will draw conclusions from the differences and similarities found.

\section{Writing skills}

When examining seventeenth- and eighteenth-century private letters, we have to take into account the contemporary circumstances of literacy and illiteracy. Although the rate of literacy in the northern Netherlands was high compared to other European countries at the time, part of the population could neither read nor write. ${ }^{3}$ We have also to bear in mind that those who were able to read may not have had any writing skills, as reading and writing were taught in succession, not simultaneously (Blaak, 2009: 3-4; Kuijpers, I997: 50I). On the basis of signature studies of marriage contracts, it is commonly estimated that two-thirds of the male population and one-third of the female population were able to write in the northern Netherlands in the second half of the seventeenth century (Frijhoff and Spies, I999: 237). Around I800, literacy had increased to about 80 per cent of the male and 60 per cent of the female population (Kloek and Mijnhardt, 200I: I8). These literates, however, may not all have used their reading and writing skills regularly. Thus not only literacy rates, but also (reading and) writing experience differed in the language community across gender, social rank, and time, as we will show elsewhere (Rutten and Van der Wal, forthcoming). Here we focus on what more and less experienced literates had in common, that is that, at some stage in life, they all had learnt to read and to write, at school, during apprenticeships or at home, either from schoolmasters or from relatives, friends, or others in their neighbourhood.

Apart from private education in the highest ranks of society, reading and writing were taught at elementary schools where, according to the regulations, schoolmasters had to make handwritten models of writing for their pupils who learnt to master the technical skill of writing different styles such as gothic and cursiva italic. From the

Around I 800 the northern Netherlands, Scandinavia, Iceland, Prussia and Scotland had less than 30 per cent male illiterates, a much lower percentage than e.g. the southern Netherlands, England, Ireland, and France (cf. Boonstra, I993: 22-23; see also Graff, 1987: 173-248). 
diary of a seventeenth-century Dutch schoolmaster, David Beck, we know that these samples of handwritings were shown to parents as a successful means of attracting new pupils (Blaak, 2009: 60-6I). Thus we may assume that parents highly valued the acquisition of different hands. A convincing proof of this assumption is found in one of the letters in our corpus, dated I4 November I664. Writing to her son Cornelis aboard a warship, Maria Walravens proudly mentions the fine writing skills of his ten- and fourteen-year-old brothers. She encloses even two of their writing proofs, which give us an idea of the writing practice of copying religious phrases in different handwritings (cf. Figure 2).

Having mastered the technical skill of writing, how did people, at a more advanced stage, learn to write a letter? We may think of various options: at school, the schoolmasters may have provided letter-writing models just as they did for writing different hands. At home, relatives may have trained youngsters by making them copy selfwritten or received letters. A similar practice of copying letters may be assumed for apprentices in various professions. Considering these options, the question remains as to what role the often-reprinted letter-writing manuals and other instructive publications may have played. Our digital letter corpora allow us to investigate the characteristics of Dutch seventeenth- and eighteenth-century private letters and to compare them with the advice and models in manuals. Do we see similarities or differences, and can we answer the question whether the manuals influenced the daily letter-writing practice or not? In order to be able to answer these questions, we will present the most frequent formulae in the following section.

\section{Formulaic language in private letters}

For this article we examined two subcorpora of Ioo seventeenth-century and Ioo eighteenth-century private letters, each of about 55,000 words. Following Wray (2002) among others, we can distinguish three main categories of formulae: the textconstitutive, intersubjective, and Christian-ritual formulae (Rutten and Van der Wal, 2OI2). The text-constitutive category consists of both text-type formulae (such as address formulae, date formulae, salutation, and opening formulae, closing formulae and signatures) and text-structural formulae such as $I k$ laat $u$ weten dat 'I let you know that' which mark the text structure and realize the transition of one part of the discourse to another. Intersubjective formulae focus on the relationship between the writer and the addressee and cover the domains of health, greetings, and contact. The Christian-ritual formulae foreground the relationship between the writer, the addressee, and the divine world, for example, in the commendation formula, with which the writer commends the addressee into the hands of God. It is important to note that formulae may combine two or three functions, with one function being dominant. The greeting formula een vriendelijke groetenisse zij geschreven aan 'a friendly greeting be written to', for example, is intersubjective in greeting the recipient, but the verbal elements zij geschreven 'be written' stress also the fact that the document is a letter and thus the formula fulfils also a text-constitutive function. 


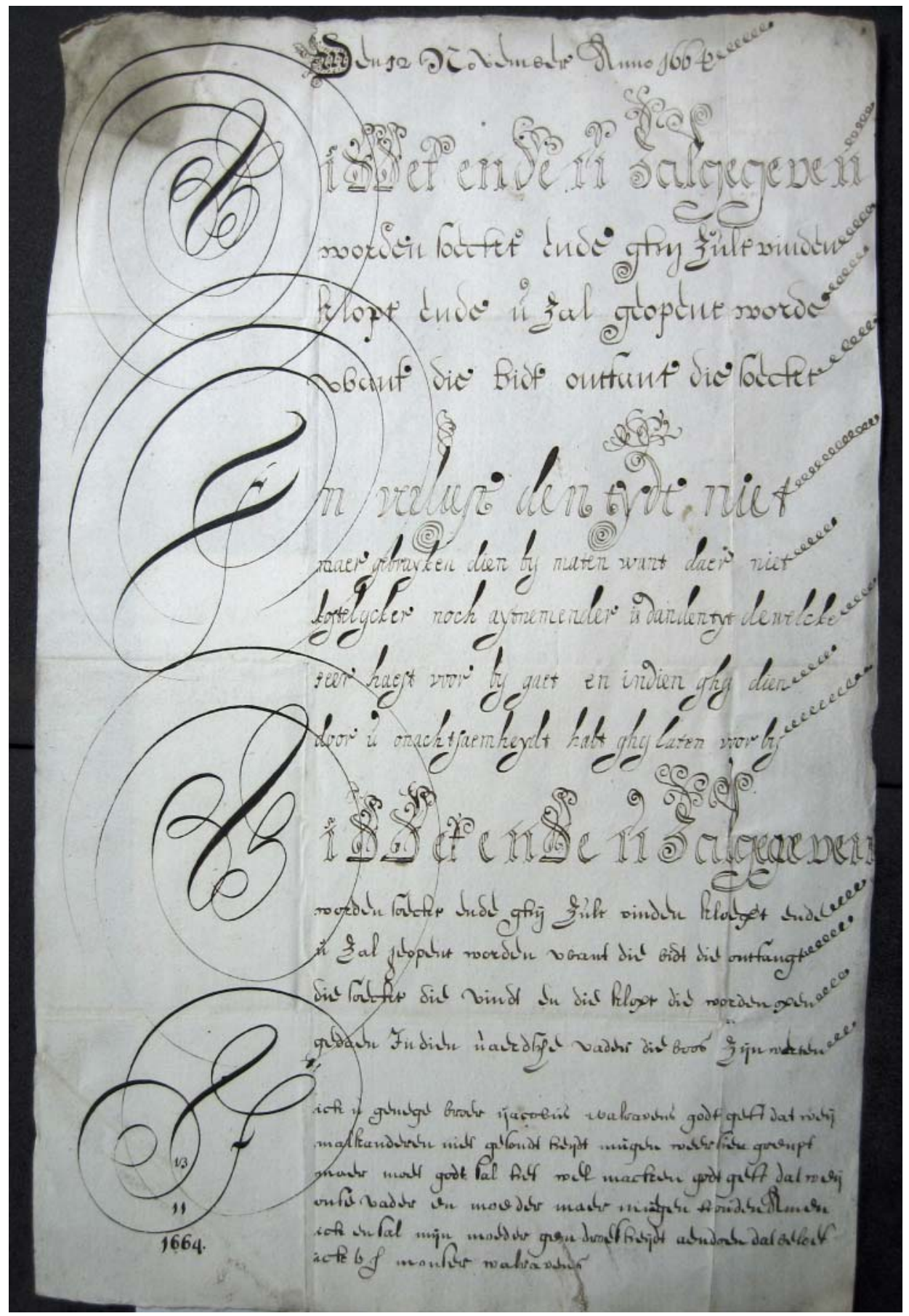

FIGURE 2 Writing proof by Jacobus Walravens. 


\subsection{Formulaic fashions: Praise to god and greeting the recipient}

Many seventeenth-century letters begin with the looft godt boven al 'praise God above all' formula, or in some cases with the reduced looft godt 'praise God' or with the extended loft godt altijt waer dat geij sijt 'praise God where-ever you are' variants. This text-constitutive formula and its variants only appear in dates; they are found in 60 out of the roo seventeenth-century letters of our subcorpus $(60 \%)$. The similar latinized formula laus deo (semper) 'praise to God always' features in seven letters $(7 \%)$, only once with the added phrase qui regnat omnia Mundi 'who reigns the whole world'. The frequently used Praise to God formula, both in its Dutch and latinized form, appears to be characteristic of only seventeenth-century letters. In our eighteenth-century subcorpus, not a single instance of this formula, neither in Dutch nor in Latin, occurs.

The absence of the Praise to God formula from eighteenth-century letters shows clearly a diachronic change in formulaic 'fashion' which will also become apparent in a few other formulae such as the above mentioned een vriendelijke groetenisse sij geschreven aan 'a friendly greeting be written to' formula. This opening formula to address the recipient occurs, its variants included, in 50 per cent of the seventeenthcentury letters. Variants of this formula show modifiers such as seer 'very' (thus 'very friendly'), different adjectives such as waerdeijge 'worthy' and hartelijke 'heartly', and omission of the verbal elements such as een vriendelijcke groetenisse aan 'a friendly greeting to'. Once again we see a diachronic effect in that the formula is absent from the eighteenth-century subcorpus.

The Praise to God and Greeting the recipient formulae are not explicitly mentioned, as far as we know, in studies of formulaic letter writing in other language areas. That is different for the intersubjective health formulae, as we will see.

\subsection{The health formula}

Jan Paal begins his brief note with a health statement and a health wish: 'dear father and brother I let you know our health hope that with father and brother also likewise is'. Such phrases are typical for the introductory part of our seventeenth-century letters where we find extensive health formulae that may add up to strings of 4,5 , or even 6 successive formulae, as shown in Table $\mathrm{r}$.

The subordinate formulae 2-6 occur immediately after an initiating health formula such as formula I. ${ }^{4}$ Similar health formulae are found in English letters from the fifteenth to the early nineteenth centuries (Davis, I965: Nevalainen, 200I; Austin, I973a; I973b; 2004). Examples from nineteenth-century Finnish are provided by Laitinen and Nordlund (2012: 77). Health statements such as formula I occur also in German, but German counterparts of the extensive formula are not mentioned by Elspaß (2005).

4 The formulae 2 and 6, which refer to God, could be considered as Christian-ritual formulae, but, since they occur only in this specific health discourse structure, we prefer considering them as subordinate health formulae. 
TABLE 1

HEALTH FORMULAE IN THE SEVENTEENTH-CENTURY SUBCORPUS

\begin{tabular}{|c|c|}
\hline & Sequence of health formulae \\
\hline 1 & $\begin{array}{l}\text { als dat ick en ul vaeder en min vaeder en moeder noch klock en gesont sein } \\
\text { 'that I and your father and my father and mother are still in good health' }\end{array}$ \\
\hline 2 & $\begin{array}{l}\text { godt sij lof van syn groote genade } \\
\text { 'Praise God for his mercy' }\end{array}$ \\
\hline 3 & $\begin{array}{l}\text { gelijck ik hoop van vl mijn lief te verstaen } \\
\text { 'as I hope to hear from you my love' }\end{array}$ \\
\hline 4 & $\begin{array}{l}\text { het welcke mijn van harten seer lief om te hooren is } \\
\text { 'which I [would] very much love to hear' }\end{array}$ \\
\hline 5 & $\begin{array}{l}\text { waer het Anders het waer ons van herten leet } \\
\text { 'if it were different, we would be very sorry' }\end{array}$ \\
\hline 6 & $\begin{array}{l}\text { dat wedt godt almachtich die en kender van alle harten is } \\
\text { 'The almighty God, who knows all the hearts, knows this' }\end{array}$ \\
\hline
\end{tabular}

In our seventeenth-century subcorpus, no less than $92(92 \%)$ letters show the health formula I, with or without a number of the subordinate formulae $2-6$. There is no doubt about their formulaic character, which is most revealing in letters where the extended formula including the Praise God phrase is followed by the mentioning of poor health or the death of a dear relative. A striking example, in this respect, is the letter from Marrietje Kortoen to her husband Pieter Rickersen, dated I I November I664, in which the extended formula I-6 and a few more lines are followed by the description of the death of their son and her own illness.

The most frequent expression for the state of health is the almost tautological formula kloeck en gesont 'strong and healthy', which has a German nineteenthcentury counterpart in gesund und munter 'healthy and lively', with variants such as gesund und wohl 'healthy and well' (Elspaß, 2005: I65). Other, less frequent Dutch health statements are wel te passe 'lit. well to state, in good health' and the collocation of the noun gesontheijt 'health' with the verb verstaen 'understand' such as Jan Paal's mijn vader en broer gesontheijt veerstan 'my father's and brother's health understood'. One of the most salient differences in formulaic language between the seventeenth and the eighteenth centuries is the relative lack of health formulae in the eighteenth century. The elaborate phrases on health, with the various subordinate formulae, virtually disappear in the eighteenth century. This does, however, not mean that the health theme is completely absent from eighteenth-century letters. It is rather incorporated in opening phrases such as Hoope UE dese ingesontheyt moogt ontfangen 'I hope that you may receive this in health'. Another remarkable difference is a change from the frequent seventeenth-century expression kloeck en gesont 'strong and healthy' to the eighteenth-century formula fris en gezond 'fresh and healthy' as in den ze Maij deezen albier fris en gezond aangeland ben ' $\mathrm{I}]$ have arrived here (being) fresh and healthy on 3 May'. 


\subsection{Diachronic continuity and change}

At the beginning of a letter, the sender often refers to earlier communication with a wide variety of formulae, both in the seventeenth- and eighteenth-century subcorpora. Some formulae explicitly state that the letter has been received such as wel overghekomen 'come over well' and Jan Paal's phrase vader ul breijf ontfangen enoock vandach een brief van mij broer 'father your letter received and also today a letter from my brother'. In her selection of late eighteenth- and early nineteenth-century letters, Austin (1973a: I5) found similar phrasings, which she refers to as 'the formula "I received your (kind) letter of" + date'. Elspaß (2005: 165) mentions nineteenth-century German examples (Deinen/Euren Brief, Dein/Euer Schreiben (vom...) habe ich/haben wir richtig erhalten/empfangen 'your letter, your writings (of ....) I/we have received well'). Sometimes attention is drawn to the contents of the previous letter(s), for which the formulae daer uijt verstaen 'lit. there from understood, understood from it' and daar uijt gesien 'lit. there from seen, seen in it' are in use. The latter has a German counterpart in und (...) (daraus/darin) gesehen/ersehen 'and seen in/understood from it' (Elspaß, 2005: 165).

Diachronic continuity is also found in the occurrence of ick laet ul weeten als dat 'I let you know that', the most frequently used text-structural formula for initiating discourse. In our seventeenth-century subcorpus, 62 tokens of this formula were found in roo letters. With 34 tokens in roo eighteenth-century letters, the formula is still fairly frequent, though not as frequent as in the previous century. This formula features also in both English and German letters of the Early and Late Modern period, for instance to let you know (Austin, 1973a: I6), um dichleuch wissen zu lassen 'to let you know', thue ich euch ze wissen 'I let you know' (Elspaß, 2005: 165, I68-70), and in Finnish letters from the nineteenth century (Laitinen and Nordlund, 20I2: 69). In our corpora, the formula in many cases immediately follows the opening of the letter, but it is also found in subsequent parts, announcing a new topic. The same topic-shifting function is fulfilled by its English counterpart to let you know, as shown by Austin (1973a: I6) in her study of eighteenth-century letters. The formula clearly structures the text of the letters which in almost all cases lack any punctuation. $^{5}$

Another stable feature is the Christian-ritual commendation formula sijt de goede godt in ghenade beuolen 'be the good God in grace commended' which also occurs in the reduced form zijt de heere bevoolen and which shows both phrasal variation and lexical variation. ${ }^{6}$ We found 65 instances of the commendation formula in the seventeenth-century and 43 tokens in the eighteenth-century subcorpus, which shows that the formula remained frequently in use in the course of time. The formula is mostly found in the ending of a letter, where it features among other closing elements

5 Note that there is not any punctuation in the seventeenth-century writing proof (Figure 2) either which could indicate that punctuation was not considered a necessary part of acquiring writing skills.

6 The addressee may be commended to God or the Lord, but also to His protection or mercy, and the protection may be expressed by the lexical variants bescherminge, protectie, and bewaringe 'lit. keeping'. 
such as in Jan Paal's phrase wensche vader en broer duesent goede nach 'wish father and brother thousand good night[s]' and in By myn Jan Jansen van tiel ul vader wat ick vermach 'by me Jan Jansen van Tiel your father whatever I can'. These two seventeenth-century closings, marked boldface here, clearly illustrate changing fashions. The formula a (bundred) thousand good nights and its variants feature in almost half of the seventeenth-century subcorpus (48\%). In the eighteenth-century subcorpus, only $\mathrm{I} 7$ instances $(\mathrm{I} 7 \%$ ) are found. The idiom wat ick vermagh 'whatever I am capable of' and its variants occur in only I5 seventeenth-century letters (I $5 \%$ ). This formula becomes obsolete: in the eighteenth-century subcorpus, not a single token is found.

After having presented this overview of frequently used formulae, we turn to the question of whether letter writers learnt these formulae from letter-writing manuals.

\section{Letter-writing manuals: Theory and practice}

The quotation from the humanist Vives, which features as a motto of this article, clearly illustrates that some formulae date from as early as Roman antiquity. Vives, Erasmus, and many of their successors gave guidelines and examples for a new trend in letter writing, characterized by imitating Cicero instead of following the medieval conventions of the so-called ars dictaminis. Guidelines depended on the types of letters which were distinguished into, for instance, letters of advice, letters of recommendation, letters of request, letters of complaint, letters of thanks, letters of congratulation, letters of consolation, et cetera (Vives, I989: 55). These categories are also found in the vernacular letter-writing instructions which show a mixture of characteristics from both the late medieval and Renaissance rhetorical art of letter writing and Latin and French models for business and legal writings, the ars notaria (see Poster and Mitchell, 2007). For early English correspondence, the complex intertwining of conventions from different traditions is addressed in, for example, Nevalainen (200I). To examine the origins of the formulaic similarities in different language areas, as noticed in the previous section, is far beyond the scope and limits of this article. The presentation of the Dutch data in a (modest) comparative perspective exhibits most of all how widespread particular letter-writing conventions were in Europe. What we aim at here is establishing the influence or lack of influence of letter-writing manuals by comparing the 'theory' of manuals with the practice of private letters.

A division into types of letters such as mentioned above typically characterizes the more elaborate Dutch manuals which offer both theory and a large selection of model letters or just a large selection of letters. The letters in these manuals, aiming at an audience fairly high up the social scale, do not show any resemblance with the formulaic language of our letter corpora (cf. for instance the frequently reprinted Mostart, 1637). The same applies to popular foreign manuals such as J. P. de la Serre's Fatsoenlicke Zend-brief-Schrijver (1654) and Nicholas Breton's Nederduytsen Briefdragher (I645), which were translated into Dutch. But there is one striking 
exception: in Breton's collection of diverting letters, we find a remarkable letter Naer d'oude manier van't Vryen 'about love making according to the old fashion' which comprises a familiar greeting and an extensive health formula, both in the Dutch translation and the English original (Breton, I645: 85-86). It is not unlikely that in this particular case of Breton's work, which is part of 'an ongoing tradition of “Merriment" or witty take-offs on standard letters' (Bannet, 2005: xv), the old fashion and its formulae were ridiculed.

Having found no other traces in what we may call elite manuals, we examined booklets targeted towards a more modest audience and/or intended to be used in elementary schools. ${ }^{7}$ There we did find formulae that occur in our letter corpora. The similarities and differences of these formulae compared with those in the letters will be discussed, while focusing on two representatives of these school books: Jacobi's Ghemeyne zeyndt-brieven 'common sending letters' and the Materieboekje 'book of matter'. ${ }^{8}$ Both booklets had various reprints without any major differences between the editions. Jacobi's manual was repeatedly published throughout the Netherlands in a period spanning more than two centuries: the first edition at least as early as I597, in Amsterdam, the latest edition I803 in Maastricht (Limburg). ${ }^{9}$ Jacobi's manual and similar books comprise only a short introduction to a relatively small number of letters or just a small number of letters. In the Materieboekje, which has survived in at least three seventeenth-century (I6I4, I686, I696) and one eighteenth-century edition (I720), letter writing is just one of the topics among other instructive texts. It provides simple letter-writing instruction by purely presenting five model letters. ${ }^{\text {IO }}$

Dealing with the formulae, we establish, first of all, that laus deo semper occurs both in the Materieboekje (in four of the five model letters) and in Jacobi's manual where we find four instances in 69 example letters (5.7\%). ${ }^{\text {II }}$ Most surprising, however, is that in both manuals not a single instance of the frequent Dutch variant looft godt boven al is found. The equally frequent a friendly greeting be written to formula does not occur in the Materieboekje either and only two instances $(2.9 \%)$ are found in Jacobi's manual.

The health formula features in four out of five letters in the Materieboekje $(80 \%)$ and in seven (Iо\%) of Jacobi's letters, in five of which together with the subordinate formulae 2 and 3 (Table I). In Jacobi's manual, the expression of the state of health varies: apart from kloek en gezond (3) and wel te passe (I), the variants kloek en sterk (I), in goeden doene (I), and a variant with the verb wel varen 'be well' (wist dat ghy

7 Particular remarks in their prefaces, mentioning the possibility of translating the example letters into Latin and French, indicate that some of them were also intended to be used in secondary education.

8 Part of this research was conducted in the MA research seminar Letters as Loot (autumn 20II, taught by Van der Wal), with contributions from Gábor Bécsi and Emma Kastelein.

9 For the present research we refer to Jacobi's I645 edition, which was printed in the province of Holland just before the period from which our seventeenth-century letters date (I660s/I670s).

ro One of the letters figures among the moral lessons, the four others form a separate unit. For the present research we refer to the I6I4 edition.

${ }^{\text {II }}$ We have excluded the Christmas, Easter, and similar letters in rhyme. 
wel vaert, soo ist wel. ick vaer ook wel, God danck 'if I knew that you are well, then it is well. I also am well, thank God') occur. The health formula is thus present in the manuals, but in a less extensive form, that is without the subordinate health formulae 4,5 , and 6 , and only in $10 \%$ of Jacobi's letters against the impressive frequency of $92 \%$ in actual usage.

The I let you know formula occurs in three out of five letters $(60 \%)$ in the Materieboekje; in Jacobi's letters eleven instances of this formula were found ( $16 \%$ ). In the case of the commendation formula, a strong resemblance with the actual seventeenthcentury letters is found. In three out of five letters in the Materieboekje the commendation formula appears $(60 \%)$, and in Jacobi's letters 42 instances of this formula were found $(6 \mathrm{I} \%)$.

Not a single instance of the frequent seventeenth-century closing formula a bundred thousand good nights occurs either in the Materieboekje or in Jacobi's manual, but in the latter publication we do come across eleven instances of the similar phrase $i k$ zendelontbiede $u$ duizend goede nachten 'I send/(re)commend you a thousand good nights' as an opening formula. This opening formula, which also occurs once in the Materieboekje, is absent from our letter corpora. The far less frequent seventeenthcentury closing formula wat ick vermach appears only once in the Materieboekje $(20 \%)$ and three times $(4.3 \%)$ in Jacobi's manual. It is surprising that this formula, which became obsolete in the eighteenth century, was still recommended in eighteenth-century reprints of Jacobi's book. Similarly, laus deo semper and a friendly greeting be written to, which both vanished from usage after the seventeenth century, survived in these reprints. The same applies to kloek en gezond which disappeared from usage and was partly replaced by fris en gezond 'fresh and healthy' in the eighteenth century. It does, however, still occur in the reprints, while fris en gezond does not.

Summarizing, both in the Materieboekje and in Jacobi's manual we find formulae similar to those found in actual usage, although mostly with different frequencies. The differences in frequency need not surprise us, as we may assume that Jacobi's manual intended to offer its readers a wide variety of more and less frequently used formulaic choices. What does surprise us, however, is the absence of the frequent looft God bovenal formula, of three subordinate health formulae and of the popular closing formula a hundred thousand good nights. Yet another striking discrepancy is the presence of formulae in Jacobi's manual that do not feature in our letters. The opening formulae ik recommanderel gebiede mij t'uwaarts/in u gratie 'I (re)commend myself to you/in your grace', oorzake mijns schrijvens is 'reason of my writing is', den waaromme van dezen is 'the reason of this is' frequently ( $10 \%$ to $20 \%$ ) occur in Jacobi's sample letters, but they do not appear in a single letter in our corpora. ${ }^{\mathrm{I} 2}$

${ }^{\mathrm{I}} 2$ The recommendation in your grace formula occurs once in the Materieboekje and the den waaromme van dezen formula twice, but even in our extended corpus of about 600 letters $(594$ letters, i.e. 2Io seventeenthcentury and 384 eighteenth-century letters), we did not find one single instance of these two formulae and only one example of the oorzake mijns schrijvens formula. 
Finally, we note that Jacobi's eighteenth-century reprints do not reflect the contemporary changes of actual formulaic usage.

\section{Reflection and conclusions}

After having established similarities and differences between the 'theory' of the more modest manuals or schoolbooks and the actual practice of private letters, we have to evaluate these results and reflect on the possible influence of the manuals on the letter writers. What do these results imply for the daily practice of letter writers and for the issue of how they acquired their formulaic language? In our view, the differences outweigh the resemblances to the extent that direct influence of letter-writing manuals on the actual practice is not very likely. If the manuals had a decisive influence, it would be difficult to explain, on the one hand, why particular formulae in the manuals do not occur in the letters at all and, on the other hand, why fairly marginal formulae in the manuals are very popular in the letters. Moreover, various frequently used formulae that are completely absent from the manuals, must have been acquired otherwise. Therefore, we have to consider another option. Although the manuals present letter-writing conventions and thus may have functioned as works of reference, it is more likely that pupils at school and youngsters at home learnt letter-writing conventions and formulaic language, and further developed their writing skills, by participation in writing practice, that is by reading and copying letters and hearing them read aloud. Similar claims have been made for English letter writing in the long eighteenth century (cf. Austin, I973a: I3; Whyman, 2009: 28-45; Brant, 2006: 9-10), for German and Finnish letters from the nineteenth century (Elspaß, 2005: I94-95; Laitinen and Nordlund, 20I2), as well as for Dutch elite correspondence from around I800 (Ruberg, 2005). This means that letter writing was probably acquired in a similar manner as other skills were: by imitation in practice, at home, at school, and at work (cf. Bannet, 2005: 94). Is it not revealing, in this respect, that the formulae written by pupil Jan Paal strongly resemble those in his mother's letter?

\section{Bibliography}

Austin, Frances. I973a. Epistolary Conventions in the Clift Family Correspondence. English Studies, 54: 9-22.

Austin, Frances. I973b. Epistolary Conventions in the Clift Family Correspondence (Concluded). English Studies, 54: I29-40.

Austin, Frances. 2004. Heaving this importunity: The Survival of Opening Formulas in Letters in the Eighteenth and Nineteenth Centuries. Historical Sociolinguistics \& Sociohistorical Linguistics, 4. Available at: <http:// www.let.leidenuniv.nl/hsl_shl/heaving_this_importunity.htm> [last accessed 28 June 20I2].

Bannet, Eve Tavor. 2005. Empire of Letters. Letter Manuals and Transatlantic Correspondence, I688-I820. Cambridge: Cambridge University Press.

Blaak, Jeroen. 2009. Literacy in Everyday Life. Reading and Writing in Early Modern Dutch Diaries. Leiden and Boston: Brill.

Boonstra, Onno W. A. I993. De waardij van eene vroege opleiding: een onderzoek naar de implicaties van het alfabetisme op het leven van inwoners van Eindhoven en omliggende gemeenten, I800-I920. Wageningen: Afdeling Agrarische Geschiedenis, Landbouw Universiteit. 
Brant, Clare. 2006. Eighteenth-Century Letters and British Culture. Houndmills and New York: Palgrave Macmillan.

Breton, N. 1645. Nederduytsen Briefdragher. Amsterdam: Jan van Hilten.

Davis, Norman. 1965. The Litera Troili and English Letters. The Review of English Studies. New Series, I6: 233-44.

Elspaß, Stephan. 2005. Sprachgeschichte von unten. Untersuchungen zum geschriebenen Alltagsdeutsch im I9. Jahrhundert. Tübingen: Niemeyer.

Frijhoff, Willem and Spies, Marijke. I999. 1650. Bevochten eendracht. The Hague: Sdu.

Graff, Harvey J. 1987. The Legacies of Literacy: Continuities and Contradictions in Western Culture and Society. Bloomington, Ind.: Indiana University Press.

Jacobi, H. I645. Ghemeyne zeyndt-brieven / profijtelijck voor de ouders / meesters ende kinderen / om te leeren brieven dichten / wel te leven / ende ordentelijck te schrijven. Hoorn: Isaac Willemsz.

Kloek, Joost and Mijnhardt, Wijnand. 200I. I800. Blauwdrukken voor een samenleving. The Hague: Sdu.

Kuijpers, Erika. I997. Lezen en schrijven. Onderzoek naar het alfabetiseringsniveau in zeventiende-eeuws Amsterdam. Tijdschrift voor Sociale Geschiedenis, 23: 490-522.

Laitinen, Lea and Nordlund, Taru. 20I2. Performing Identities and Interaction Through Epistolary Formulae. In: Marina Dossena and Gabriella Del Lungo Camiciotti, eds. Letter Writing in Late Modern Europe. Amsterdam and Philadephia: John Benjamins, pp. 65-88.

Materi-boecxken, oft voorschriften / seer bequaem voor die Joncheyt / om wel te leeren lesen / schryven / ende een aenporringhe tot alle deuchden. I6I4. Utrecht: Harman Hendricks van Borculo.

Mostart, D. 1637. Nederduytse secretaris oft zendbriefschryver, met een tytelboexken. Amsterdam: Dirck Pietersz.

Nevalainen, Terttu. 200I. Continental Conventions in Early English Correspondence. In: Hans-Jürgen Diller and Manfred Görlach, eds. Towards a History of English as a History of Genres. Heidelberg: Universitätsverlag C. Winter, pp. 203-24.

Poster, Carol and Mitchell, Linda C. 2007. Letter-Writing Manuals and Instruction from Antiquity to the Present. Columbia: The University of South Carolina Press.

Ruberg, Willemijn. 2005. Conventionele correspondentie. Briefcultuur van de Nederlandse elite, I770-I850. Nijmegen: Vantilt.

Rutten, Gijsbert and van der Wal, Marijke. 20I2. Functions of Epistolary Formulae in Dutch Letters from the Seventeenth and Eighteenth Centuries. Journal of Historical Pragmatics, I3: 173-20I.

Rutten, Gijsbert and van der Wal, Marijke. forthcoming 20I3. Epistolary Formulae and Writing Experience in Dutch Letters from the Seventeenth and Eighteenth Centuries. In: Marijke van der Wal and Gijsbert Rutten, eds. Touching the Past. Studies in the Historical Sociolinguistics of Ego-documents. Amsterdam: John Benjamins.

Serre, J. P. de la. 1654. Fatsoenlicke Zend-brief-Schrijver. Amsterdam: Jacob Benjamin.

Vives, Juan Luis. 1989. De conscribendis epistolis, ed. by Charles Fantazzi. Leiden: Brill.

Van der Wal, Marijke, Rutten, Gijsbert, and Simons, Tanja. 20I2. Letters as Loot. Confiscated Letters Filling Major Gaps in the History of Dutch. In: Marina Dossena and Gabriella Del Lungo Camiciotti, eds. Letter Writing in Late Modern Europe. Amsterdam, pp. I39-43.

Whyman, Susan E. 2009. The Pen and the People. English Letter Writers 1660-I800. Oxford: Oxford University Press.

Wray, Alison. 2002. Formulaic Language and the Lexicon. Cambridge: Cambridge University Press.

\section{Notes on contributors}

Marijke van der Wal is Professor in the History of Dutch (Chair Merweborgh Foundation) at Leiden University where she directs the research programme Brieven als Buit/ Letters as Loot. Towards a non-standard view on the history of Dutch (<www.brievenalsbuit.nl>). 
Correspondence to: Marijke van der Wal, Leiden University, Department of Dutch Language and Culture, P.N. van Eyckhof I, PO Box 95I5, 2300 RA Leiden, The Netherlands. Email: m.j.van.der.wal@hum.leidenuniv.nl

Gijsbert Rutten is Assistant Professor and Researcher working at Leiden University and at the Vrije Universiteit Brussel.

Correspondence to: Gijsbert Rutten. Email: g.j.rutten@hum.leidenuniv.nl

Both authors have published in the fields of historical linguistics and the historiography of linguistics. Their current sociohistorical linguistic research focuses on ego-documents and language history from below. 